\title{
CETP Gene
}

National Cancer Institute

\section{Source}

National Cancer Institute. CETP Gene. NCI Thesaurus. Code C39780.

This gene plays a role in the transfer of cholesteryl esters between lipoproteins and has been implicated in atherosclerosis susceptibility. 